\title{
Review of The Archaeology of Andean Pastoralism edited by José M. Capriles and Nicholas Tripcevich
}

\author{
Robin Bendrey
}

\author{
Book details \\ Capriles J M and Tripcevich $\mathrm{N}$ (eds.) \\ The Archaeology of Andean Pastoralism \\ Albuquerque: University of New Mexico Press; 2016. \\ 280 pages, 87 figures, 25 tables \\ ISBN 978-0-8263-5702-1
}

Keywords: Andes, South America, Camelids, Archaeology, Ethnography

The Andes are huge. Rising to a maximum height of over $4 \mathrm{~km}$ above sea level along their tropical and subtropical portions and extending north-south up the spine of South America, they structure regional geography, climate and biodiversity (Garreaud 2009). This landscape is the backdrop to the studies presented in this volume, which cover human-camelid relationships in contexts from the Peruvian coast to the Andean highlands and from northern Peru to southern Bolivia.

The volume was born in a multi-session event at the Annual Meeting of the American Anthropological Association in 2012. It pulls together and summarises recent research in Andean camelid pastoralism. There are 22 contributors to the volume, including many of the key scholars on the topic. Following an introduction by the editors, Tripcevich and Capriles, identifying the key themes and advances of the volume, there are 13 main chapters and one commentary piece by Browman which offers a thoughtful and critically robust reflection on the contributions of the chapters.

In a short chapter, Kuznar explores the effect of mobile pastoral groups in the Andes on wider economic and social stability in the context of global pastoralism studies. The role of mobile pastoralists in economic integration, through the transport of animals and goods

Correspondence: robin.bendrey@ed.ac.uk

School of History, Classics and Archaeology, University of Edinburgh, William Robertson Wing, Old Medical School, Edinburgh, UK between different areas, is evident, though the validity of some of the comparative ethnological case studies could be further explored in terms of the destabilising roles of pastoral groups. Moore's chapter considers the early domestication of camelids in the Andes, the processes that underpin the later development of pastoralism. There are four extant camelid species: two wild species, guanaco (Lama guanicoe) and vicuña (Vicugna vicugna); and two domestic, llama (Lama glama) and alpaca (Lama pacos). There is still some uncertainty concerning the relationships between these taxa: while it is known that llamas were domesticated from guanacos, there is conflicting genetic evidence for the origins of the alpaca with different studies suggesting the guanaco and the vicuña (Irving-Pease et al. 2018). The lack of clarity may be due to population bottlenecks in the recent wild camelids and may only be fully resolved through analysis of archaeological populations (Irving-Pease et al. 2018). As Moore describes, anatomical and physiological similarities suggest that the vicuña is the ancestor of the alpaca-both have a more restricted high-altitude range, higher water requirements and inability to deal with aridity. Moore's chapter provides a masterful exploration of the complex archaeological record of the gradual emergence of camelid domestication through a detailed multi-proxy approach. She argues well for the importance of camelid domestication as a globally important 
case study which contrasts with Old World domestications.

Capriles examines the faunal remains recovered from and around a Wankarani cultural complex Formative Period house (c. $200 \mathrm{BCE}-100 \mathrm{CE}$ ) located in the Altiplano of Oruro, western Bolivia. Capriles' detailed analysis of the zooarchaeological evidence suggests seasonal use of the site and that animals were being raised for meat as well as the so-called secondary products (wool production and transportation). Another important animal secondary product is dung, often a vital fuel resource for early pastoralists, especially in treeless environments (Matthews 2016). Bruno and Hastorf analyse carbonised seed remains from burnt dung deposits at sites on the Taraco Peninsula, Bolivia. These studies offer a window on the different plants and landscape zones utilised to articulate the ecology of camelid herding. Dung is one of the many aspects also explored by Vallières in terms of the roles of camelid pastoralism in urban provisioning of the ancient city of Tiwanaku in the highlands of Bolivia. Dating to c. 500-1150 CE, the city was the centre of an important region. Vallières provides a substantial review of data strands, also supported by zooarchaeological work by the author at the Mollo Kuntu area of Tiwanaku, although it would have been useful to have greater detail from this case study.

Moving to southern Peru, Vining investigates settlement pattern shifts in the Lake Suches region between the pastoral villages on the Middle-Late Formative Period (c. $800 \mathrm{BCE}-500 \mathrm{CE}$ ) and the dispersed hamlets of the subsequent Middle Horizon (c. 500-1000 CE). He presents the archaeological, ecological and palaeoenvironmental evidence for the fissioning of these pastoral communities, and based on some fascinating models reconstructing herd sizes, proposes improved stocking rates associated with settlement proximity to bofedales, highly productive high elevation wetlands, in the latter period. Vining proposes the shift may be associated with demand for alpaca wool related to Tiwanaku economic influence. The chapter by deFrance, also focussing on southern Peru, examines the history of camelid pastoralism in the Osmore River system over a long and detailed archaeological record, from the Archaic Period to the Spanish occupation. Taking a political ecology approach, Lane and Grant investigate pastoralist expansion in Late Intermediate Period Peru (c. 1000-1450 CE). They explore the evidence for human alteration of the landscape, to manage water and soil and to increase usable pasture at lower altitudes. Lane and Grant make the valuable observation that the ecological ranges and limits of animals and plants are not immutable and can be altered through deliberate decisions.

Staying in Peru, Perales Munguía discusses the socio-political organisation of agropastoral communities in the upper Ricrán Valley in the highlands of Junín during the Late Intermediate Period (c. 1000-1450 CE) and the Late Horizon (c. 1450-1533 CE). Through a detailed analysis of settlement patterns, corrals and tombs, he identifies a transition from a focus on pastoral to agricultural production following the Inka conquest of the upper Ricrán and explores the wider socio-political implications of this change. In addition to the economic and ecological dimensions of Andean pastoralism, contributions to the book also explore the cultural role of camelids in social and ritual space. Chapters by Kent et al. and Goepfert and Prieto discuss camelid sacrifices associated with human burials at sites in the coastal region of northern Peru. These studies explore the ritual actions and community significance of these practices.

The final two chapters present studies of contemporary pastoralists. In a wonderfully rich ethnoarchaeological study, Tripcevich details a journey with llama caravan drivers in southern Peru transporting rock salt. $\mathrm{He}$ is particularly interested in travel strategies, route selection and the role of ritual. Such journeys are undertaken for economic gain, but also to maintain kinship ties. This study again underlines the archaeological importance of understanding mobile communities that occupy shifting temporary settlement locations and the routes they use through landscapes. Based on another ethnoarchaeological study in the southern Bolivian Altiplano, conducted between 1991 and 1995, Nielsen investigates home emplacement in Cerrillos, a pastoralist community of some 39 households comprising 180 people. Nielsen explores how they bond with places and make their homes, based on various factors including the distribution of resources necessary for human and animal subsistence, but also social interactions between people and non-human persons such as the llamas, mountains and animated artefacts. Nielsen does not argue that the rituality of these practices is analogous to past ones, but that as they are non-arbitrary, then attention to archaeological ritual and its materiality can offer valuable insights on past pastoral societies.

This volume represents a major pulling together and updating of scholarship on the study of Andean pastoralism and presents the theoretical and methodological framework for the next research agenda for this topic. In terms of the latter, it is clear that scientific approaches will play a key role in the years ahead, from the insights that ancient DNA can shine on domestication processes (Irving-Pease et al. 2018) to the reconstruction of animal diet, ecology and mobility via techniques such as stable isotope analysis (Dufour et al. 2014). Recurrent themes that link the chapters are the relationships between people, animals, natural resources and landscapes. Adaptation and change is a notable feature of the archaeological record. Studying pastoralism as an adaptive 
strategy to manage the risk of spatially and seasonally varying resources is a key element for understanding the human past in the Andes mountains, as it may also be for contemporary and future challenges as the editors remind us. The social dimensions of Andean pastoralism also run deeply through these studies. Clearly articulated in the ethnoarchaeological studies, these are also evident archaeologically through the incorporation of camelids in ceremonies and rituals. This is undeniably a landmark volume. Robustly tied together by the editors and attractively presented, it is core reading for anyone working on South American pastoralism and also comparative international case studies on pastoralism, domestication or human ecology.

\section{Acknowledgements}

Not applicable

\section{Funding}

Not applicable

Availability of data and materials

Not applicable

\section{Author's contributions}

The author read and approved the final manuscript.

Ethics approval and consent to participate

Not applicable

\section{Consent for publication}

Not applicable

\section{Competing interests}

The author declares that he has no competing interests.

\section{Publisher's Note}

Springer Nature remains neutral with regard to jurisdictional claims in published maps and institutional affiliations.

Received: 13 February 2019 Accepted: 14 February 2019

Published online: 05 March 2019

\section{References}

Dufour, E., N. Goepfert, B. Gutiérrez Léon, C. Chauchat, R. Franco Jordán, and S.V. Sánchez. 2014. Pastoralism in northern Peru during pre-Hispanic times: Insights from the Mochica Period (100-800 AD) based on stable isotopic analysis of domestic camelids. PLoS One 9 (1): e87559.

Garreaud, R.D. 2009. The Andes climate and weather. Advances in Geosciences 22: 3-11. Irving-Pease, E.K., K. Evan, H. Ryan, A. Jamieson, E.A. Dimopoulos, G. Larson, and L. A.F. Frantz. 2018. Paleogenomics of animal domestication. In Paleogenomics, Population Genomics, ed. C. Lindqvist and O.P. Rajora, 107-139. Cham: Springer.

Matthews, W. 2016. Humans and fire: Changing relations in early agricultural and built environments in the Zagros, Iran, Iraq. The Anthropocene Review 3: 107-139.

\section{Submit your manuscript to a SpringerOpen ${ }^{\circ}$ journal and benefit from:}

- Convenient online submission

- Rigorous peer review

- Open access: articles freely available online

- High visibility within the field

- Retaining the copyright to your article 